\title{
Optimization of in vitro lily culture system with different treatments of taurine
}

\author{
Sang-Hee Lee $\cdot$ Hwan-Rae Yang $\cdot$ Sun Tae Kim $\cdot$ Tae Hwan Jun Yong Chul Kim $\cdot$ Jong Bo Kim
}

Received: 6 December 2017 / Revised: 19 December 2017 / Accepted: 19 December 2017

(C) Korean Society for Plant Biotechnology

\begin{abstract}
Lilies as cut flowers are one of the most popular ornamental plants in South Korea. It is necessary to develop lily cultivars with high qualities. Therefore, highly efficient propagation systems are needed following release of elite cultivars. In this study, we used taurine treatment to improve the growth conditions including shoot and bulb formation, fresh weight gain, and reduction of rooting and browning.

We experimentally evaluated the effect of taurine as a growth stimulator, at concentrations of $0,2.5,5,10,15$ and $20 \mathrm{mg} / \mathrm{l}$. The results showed that $20 \mathrm{mg}$ of taurine enhanced shoot formation by $85 \%$ and increased fresh weight 5.5 -fold, which was higher than the approximately four-fold increase in the control. In addition, multiple bulb formation rate was increased by $80 \%$ and rooting by $82 \%$ following exposure to $20 \mathrm{mg} / \mathrm{l}$ of taurine. The efficiency of taurine treatment was higher than that of control with $50 \%$ multiple bulb formation rate and $60 \%$ rooting rate. The browning was $10.6 \%$ at 2.5 $\mathrm{mg} / \mathrm{l}$ of taurine when compared with $0.8 \%$ at $20 \mathrm{mg} / \mathrm{l}$. Taurine showed a positive effect on the overall growth of lily plants in terms of increased fresh weight, shoot formation rate, rooting, and formation of multiple bulbs, indicating that
\end{abstract}

${ }^{\dagger}$ Contributed equally

S. H. Lee ${ }^{1 \dagger} \cdot$ H. R. Yang ${ }^{\dagger} \cdot$ J. B. Kim $(\bowtie)$

건국대학교 의료생명대학 생명공학과

(Department of Biotechnology, College of Biomedical \& Health Sciences, Glocal Campus. Konkuk university, Choong-Ju, 27478, Korea)

e-mail: jbhee1011@kku.ac.kr

S. T. $\operatorname{Kim}^{\dagger} \cdot$ T. H. Jun • Y. C. Kim

부산대학교 생명자원환경과학대학 식물생명과학과

(Department of Plant Bioscience, Pusan National University, Miryang, 627-706, South Korea) taurine can be used as an alternative to amino acids or as an antioxidant such as citrate and vitamin $\mathrm{C}$ in plant tissue culture.

Keywords Browning, lily, mass propagation, regeneration, taurine

\section{서 언}

우리 나라에서 절화 및 분화용으로 이용되는 나리는 장미, 카네이션 등과 함께 세계적으로 인기 있는 절화 작물 중 하 나로, 전 세계적으로 335 종으로 구성된 백합 속에 속한다 (Govaerts 2013). 2015년을 기준으로 나리 재배면적은 161 ha, 생산량은 29 백만 본, 판매액은 171 억원을 기록하고 있다 (MIFAFF, 2015). 나리의 원산지는 히말라야 지역으로서 중 국, 한국, 대만 그리고 일본을 포함하는 아시아 지역과 북미 지역에 분포하고 있다. 국내에는 주로 오리엔탈 나리, 아시 안틱 나리 및 나팔나리가 주로 재배 및 보급되고 있으며 (Yoo and Kim 2006), 그 중 오리엔탈 나리가 대부분을 차지한 다(MIFAFF 2015). 그러나 원예적으로 중요한 절화 임에도 불구하고 대부분 수입에 의존하고 있고 이마저도 바이러스 에 감염된 구가 많은 실정이다(Woo et al. 2004). 다양한 소비 자의 요구도를 만족시키고 기후변화에 따른 품질저하 등을 방지하기 위해서 우량 나리품종개발이 시급하다(Kim 2017) 이러한 나리의 우량품종을 육성하기 위해 전통교배기법 및 배수체 육종 등이 도입되어 왔는데, 최근엔 유전자총 (Kim 2017)이나 아그로박테리움을 이용한 생명공학기법 (Liu et al. 2010; Wang et al. 2012)이 도입되고 있는 실정이다. 우량품종 개발 후에 식물조직배양이나 인편번식법을 도입 하는데 바이러스 무병구만 확보되면 인편번식이 주로 사용 
된다(Jeong 1998; Marinangeli and Curvetto 1997). 그러나 이러 한 무병종구 확보가 힘들어 많은 조직배양 기법이 나리 대량 증식 체계 확립에 이용되어 왔다. 나리의 경우, 무병주를 생 산하기 위하여 인편(Joshi and Dhar 2009), 경정(Liu et al. 2011), 엽조직(Tang et al. 2010) 및 약(Han et al. 1997) 등을 이용해왔 다. 캘러스에서 신초를 재분화 시키는 간접 재분화 방식 또 는 인편에서 신초가 재분화하는 직접 기관분화 방식 모두 사 용되어 오지만 나리 품종마다 차이가 크고 변이발생 문제로 인해 캘러스를 통한 간접 재분화 방식의 보편적인 적용은 문 제가 있는 실정이다. 또한 나리 조직배양 기간에 따라 변이 체 및 갈변화 발생과 과수화 현상 그리고 재분화 효율 감소 등의 문제도 해결해야할 과제이다.

나리 기내 생물체의 생육을 향상시키기 위하여 도입된 여 러 방법들 중 특히 기내 배양 중 발생하는 스트레스 및 페놀 물질에 의한 기내 식물의 갈변화로 인한 생육저하가 문제가 되는데 이를 해결하기 위하여 ascorbic acid 및 질산은 처리 (Roh et al. 2013)에 의해 나리 기내 식물체 촉진을 연구한 보 고도 있었다. 또한 식물은 자체적으로 페놀물질을 방어차원 에서 가지고 있는데 이러한 페놀은 산화되면 효소 활성을 저 하시키고 배지와 절편체의 갈변화를 유도하여 생육불량 문 제 또는 조직의 괴사를 야기시킨다(Arnoldos et al. 2001; Ozygit 2008). 그리고 이러한 상처부위에 잔류하는 페놀화합 물들이 식물조직배양 기간 동안에 발생하는 갈변화에도 영 향을 미친다고 알려져 있다(Ozyigit 2008).

이러한 문제를 해결하기 위해서 식물에 적용될 수 있는 여 러 항산화 물질 중 페놀화합물의 산화반응을 방지하기 위하 여 비타민 $\mathrm{C}$ 나 구연산 등이 많은 조직배양 연구에서 사용되 어 왔다(Paek 2001). Roh 등(2013)은 구연산 및 비타민 C와 질 산은을 사용해서 갈변화 감소 연구를 수행한 바 있다.

최근 연구에 의하면 타우린은 아미노산 형태로 영양성분 을 강화하는 방향으로 작용해서 식물의 생장을 촉진시킨다 고 보고 되었다(George et al. 2008; Zoltan et al. 2011). 메티오닌 과 시스테인에서 합성되는 타우린을 식물조직배양에 첨가 시 아미노산 첨가와 유사한 식물 생장촉진 효과를 기대할 수 있다(Lee 2015). 실제로 글루탐산 처리 시 담배캘러스 생장 이 촉진되었는데 이는 아미노산의 세포분열, 세포집단 생장 및 식물체 분화에 긍정적인 효과가 있기 때문이다(Lee 2015). 일부 귤나무 속(Ferreira and Lima-Costa 2006) 및 목본 과수류 (Druart 1988) 식물조직배양에서도 사이토키닌 유사효과를 나타내었다. 이 외에도 Hao 등(2004)이 수행한 밀 유묘를 대 상으로 한 연구에서 타우린이 식물생장촉진 효과가 있다고 보고한 바 있다.

본 연구에서는 타우린 처리에 의한 나리 식물체 조직배양 에서 신초 및 구근형성, 생체중 증가 및 발근율 향상 등의 생 장촉진 효과뿐만 아니라 갈변율 감소효과 여부를 구명하고 자 본 실험을 수행하였다.

\section{재료 및 방법}

\section{식물재료}

본 실험에 재료로 사용된 나리 식물체는 국립원예특작과학 원 화훼과에서 육성한 '레드플레임' 품종의 기내식물체로 부터 인편을 분리하여 MS basal salts with vitamins (Murashige \& Skoog, 1962)에 plant agar (Duchefa, Haarlem, The Netherlands) $7.0 \mathrm{~g} / 1$, sucrose (Duchefa, Haarlem, The Netherlands) $30 \mathrm{~g} / 1$ 을 첨 가되고 $\mathrm{pH}$ 는 5.8 로 조정된 인편증식용 $\mathrm{MS}$ 배지에서 4주 간 격으로 계대배양으로 증식한 인편조직들을 실험 재료로 사 용하였다. 모든 기내 배양은 $251^{\circ} \mathrm{C}, 16$ 시간 광주기에 광도는 약 3,500 lux 조건 하에서 수행하였다.

\section{신초 및 구경 형성율 촉진 효과}

기본 MS배지에 sucrose $30 \mathrm{~g} / 1$ 그리고 plant agar (Duchefa, Haarlem, The Netherlands) $7 \mathrm{~g} / 1$ 를 첨가하고 $121^{\circ} \mathrm{C}, 20 \mathrm{~min}$ 고압 증기멸균 하였으며, 이 기본배지에 타우린 (Duchefa, Haarlem, The Netherlands)을 $0,2.5,5,10,15$ 및 $20 \mathrm{mg} / \mathrm{L}$ 의 농도로 첨가하 였다. 약 $25 \mathrm{~mL}$ 씩 분주한 직경 $9 \mathrm{~cm}$ 페트리디쉬(SPL, Korea) 에 ‘레드플레임' 품종 인편을 용기당 30 개씩 치상 하고 4주 간 배양한 후, 신초발생율, 생체중 및 갈변율을 관찰하였다.

\section{식물체 발근 및 순화}

신초가 형성된 '레드플레임' 기내 나리식물체를 상기 기본증 식배지에 IBA $0.5 \mathrm{mg} / 1$ 그리고 위와 동일한 농도 $(0,2.5,5,10,15$ 및 $20 \mathrm{mg} / \mathrm{l}$ 로 타우린이 첨가된 발근배지로 옮긴 후 4주 후에 발근율을 조사하였다. 4-6주 후, 생육이 우수하고 발근이 잘된 개체들은 1-2주간의 순화과정을 거쳐 원예용 혼합 상토가 들 어있는 직경 $10 \mathrm{~cm}$ 화분으로 이식하여 증식과정을 수행하였 고, 상기 모든 과정에서 계대배양은 4주 간격으로 수행하였다.

\section{통계처리}

모든 처리구는 각 30 개씩 나리 인편을 사용하여 4-5반복으 로 실험을 수행하였으며, 모든 통계처리는 SPSS (window version)로 던컨다중검정 (DMRT)에 의한 ANOVA 검정을 수 행하였다.

\section{결과 및 고찰}

신초 형성 및 생체중 증가 효과

주로 동물에서 많이 발견되고 황을 함유하는 아미노산으로 

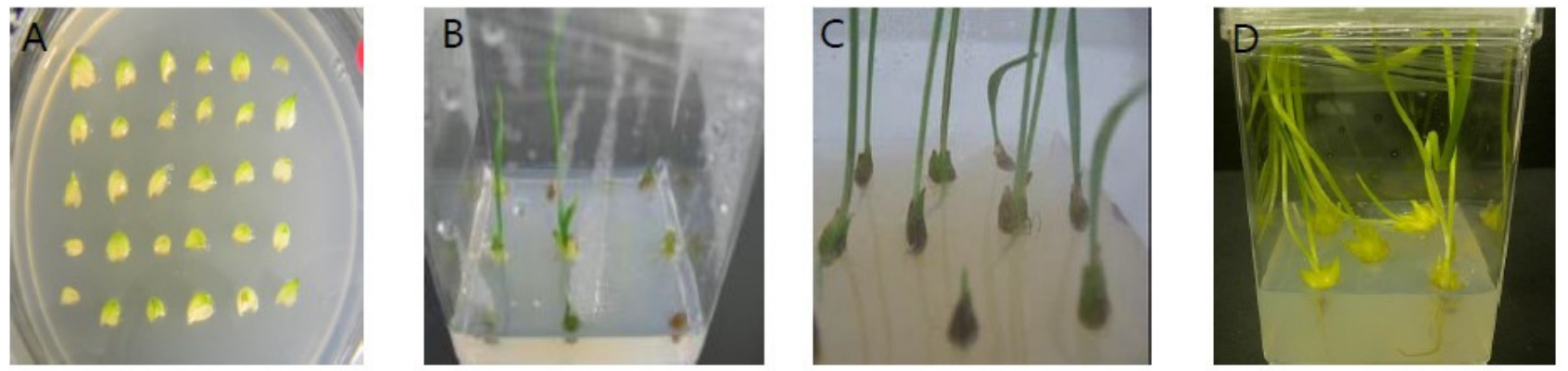

Fig. 1 Regeneration of lily plants under taurine treatment (A: scales after 3 days of culture; B: Shoot formation after 3-4 weeks of culture; C: Growth of shoots with roots; D: In vitro lily plants with multiple shoots, bulbs and vigorous roots

Table 1 Effect of different concentrations of taurine on the shoot number and fresh weight in scales of Lilium longiflorum "red flame"

\begin{tabular}{ccc}
\hline Concentrations of taurine $(\mathrm{mg} / \mathrm{l})$ & \% of shoots with scales* & Indices of fresh weight increase** \\
\hline 0 & $67.5 \pm 2.3^{* * *} \mathrm{c}$ & $4.35 \pm 0.2 \mathrm{~b}$ \\
2.5 & $65.0 \pm 2.5 \mathrm{c}$ & $4.57 \pm 0.3 \mathrm{~b}$ \\
5.0 & $72.5 \pm 1.0 \mathrm{~b}$ & $5.29 \pm 0.1 \mathrm{ab}$ \\
10 & $75.0 \pm 3.3 \mathrm{ab}$ & $5.21 \pm 0.2 \mathrm{ab}$ \\
15 & $82.5 \pm 2.5 \mathrm{a}$ & $5.37 \pm 0.2 \mathrm{a}$ \\
20 & $85.0 \pm 1.7 \mathrm{a}$ & $5.49 \pm 0.3 \mathrm{a}$ \\
\hline
\end{tabular}

*Data were collected after 4 weeks of culture, **Data were collected after 8 weeks of culture

$* * *$ Values are shown as meansMeans followed by the same letters in each column are not significantly different $(\mathrm{p}<0.05)$ using DMRT (Duncan's Multi Range Test).

작용해온 타우린은 주로 계란, 고기나 생선 등의 동물조직 에서 발견되는 아미노산이며 일부 홍조류를 제외하고는 식 물에서는 발견되지 않는 물질인데 아마 진화하는 과정에서 식물이 타우린을 이용하거나 합성하는 능력을 상실했을 것 으로 추정된다(Lee 2015). 최근 연구에 의하면 타우린은 아 미노산 첨가와 유사한 효과를 나타나는 것으로 토마토(Lee 2015) 및 귤(Ferreira and Lima-Costa 2006) 및 일부 목본류 식물 조직배양에서 보고 되었다(Druart 1988).

타우린을 기본 $\mathrm{MS}$ 배지에 $0,2.5,5,10,15$ 및 $20 \mathrm{mg} / 1$ 첨가하 고 1 개 페트리디쉬에 30 개 인편을 배양한 결과(Fig. 1A), 20 $\mathrm{mg} / \mathrm{l}$ 에서 $85 \%$ 의 신초형성률을 나타내었고 생체중도 무처리 구가 4.35 배 증가한 반면 $20 \mathrm{mg} / 1$ 처리구에서는 5.5 배정도 증 가하였다(Table 1). 배양 2 3주부터 신초가 형성되기 시작 하여 4주 후에는 뚜렷하게 많은 인편절편체에서 신초가 형 성되었다(Fig. 1B).

Lee(2015)의 토마토 캘러스에 타우린을 처리한 실험에서 도 타우린 무처리구와 비교해서 생체중이 증가함을 보여 주 었는데, 특히 이러한 경향은 고염 조건이나 과산화수소 같 은 외부 산화스트레스 처리 후 타우린 무처리 캘러스와 비교 시 타우린 처리 배지에서 자란 캘러스가 회복이 더 빠르다는 연구결과가 나왔다.

이 연구에서 $\mathrm{NaCl}$ 및 과산화수소수를 전처리 한 후, 타우 린 처리구와 무처리구를 비교한 실험에서도 타우린 무처리
구와 비교해서 타우린 처리구 캘러스는 캘러스 당 신초 개수 도 많았고, 신초 형성까지의 시간이 적게 걸림을 보고 하였다.

\section{구근형성 및 발근율 촉진 효과}

나리 조직배양에서 타우린이 구근 형성 및 발근율 촉진효 과가 있는지 알아보기 위해서 타우린을 기본 $\mathrm{MS}$ 배지에 0 , $2.5,5,10,15$ 및 $20 \mathrm{mg} / 1$ 첨가한 결과, $20 \mathrm{mg} / 1$ 에서 평균 30 개 인 편 절편체 중 24 개 인편절편체에서 multiple 구근이 형성된 반면, 무처리구에서는 절반 정도인 15 개정도에서 multiple 구근이 관찰되었다(Table 2).

또한 발근율도 타우린 $20 \mathrm{mg} / 1$ 처리구에서 $82 \%$ 의 발근율 을 나타낸 반면, 무처리구에서는 $60 \%$ 로서 다소 낮은 발근율 을 나타내었다. 신초가 형성된 기내 나리 식물체들을 IBA $0.5 \mathrm{mg} / 1$ 가 첨가된 발근 배지로 이식하면 1 2주내로 뿌리가 형성되고(Fig. 1C), 하나의 구근 외에 여러 개의 multiple 신초 와 구근들이 생긴다(Fig. 1D). 이러한 multiple 신초와 구근을 분할해서 증식배지로 옮기면 더 많은 나리 기내 식물체 증식 이 가능하여 나리 대량번식체계 확립에 기여하리라 판단된 다. Roh 등(2013)의 연구에서는 구연산, 비타민 C와 질산은 3 처리 모두 발근율에 부정적인 효과를 보여 주었다. 발근이 된 나리 기내 식물체들은 multiple 구근과 신초를 형성하고 난 후, 추가로 4 주간의 배양을 거쳐 다시 $1-2$ 주간의 순화를 
Table 2 Effect of different concentrations of taurine on bulb number and root formation rates in scales of Lilium longiflorum "red flame"

\begin{tabular}{ccc}
\hline $\begin{array}{c}\text { Concentrations of taurine } \\
(\mathrm{mg} / \mathrm{l})\end{array}$ & $\begin{array}{c}\text { \# of multiple bulbs with scales } \\
\text { scales* }\end{array}$ & $\%$ of scales with shoots and roots** \\
\hline 0 & $15.3 \pm 1.4 * * \mathrm{c}$ & $60.0 \pm 2.5 \mathrm{c}$ \\
2.5 & $16.0 \pm 4.2 \mathrm{c}$ & $55.0 \pm 2.5 \mathrm{c}$ \\
5.0 & $17.5 \pm 3.3 \mathrm{bc}$ & $66.5 \pm 3.3 \mathrm{~b}$ \\
10 & $20.3 \pm 2.5 \mathrm{~b}$ & $72.5 \pm 4.8 \mathrm{ab}$ \\
15 & $22.4 \pm 3.4 \mathrm{a}$ & $79.1 \pm 6.5 \mathrm{a}$ \\
20 & $24.2 \pm 3.2 \mathrm{a}$ & $82.0 \pm 7.5 \mathrm{a}$ \\
\hline
\end{tabular}

*Data were collected after 6 weeks of culture, **Data were collected after 8 weeks of culture

***Values are shown as meansMeans followed by the same letters in each column are not significantly different ( $\mathrm{p}<0.05$ ) using DMRT (Duncan's Multi Range Test).

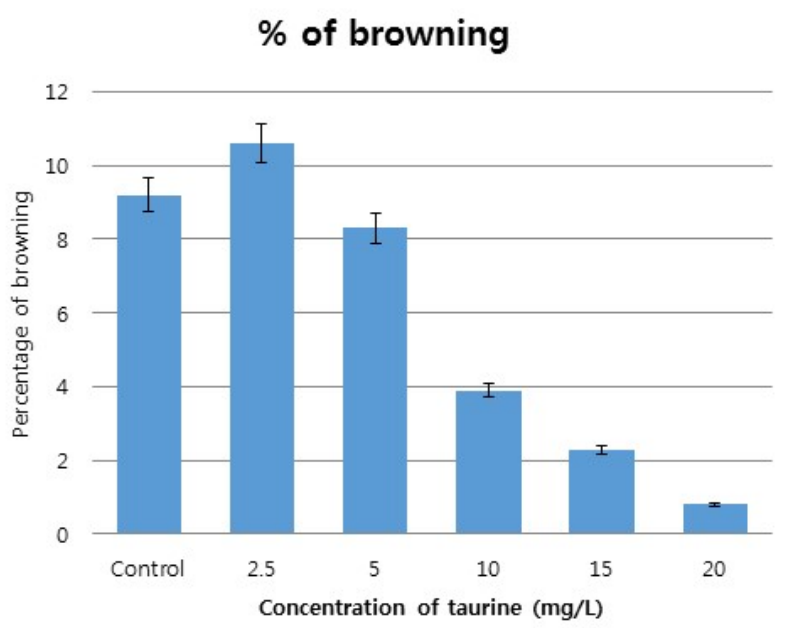

Fig. 2 Effects of taurine treatment on browning in bulb scales of lily plants after 4 weeks of culture

\section{거쳐 $95 \%$ 이상의 활착율을 보여 주었다.}

Lee(2015)의 토마토 캘러스를 대상으로 한 타우린 처리 연 구에서 나타나듯이 타우린은 동물세포나 조직에서 보여준 것처럼 식물조직배양에서 유용한 항산화제로서 사용될 가 능성이 높다고 볼 수 있다. 이 연구에서 타우린 처리구가 전 반적인 캘러스의 생체중 증가, 신초갯수 증가 및 스트레스 조건에서의 빠른 회복 효과를 보여 주었다. 또한 Hao 등 (2004)의 연구에 의하면 타우린은 밀 유묘에서 생장을 촉진 하였는데, 이 연구에서도 타우린이 식물생장을 촉진하는 물 질로서의 가능성을 기술하였다.

\section{갈변화 감소효과}

바나나 조직배양에서 페놀화합물에서 형성된 퀴논에 의해 배지와 식물조직이 갈변된다는 연구가 Ko 등(2009)에 의해 보고 되었는데, 이 연구에서 비타민 C와 질산은 처리를 통해 갈변화 현상이 감소하였다. 특히 비타민 $\mathrm{C}$ 는 갈변 현상을 방
지할 뿐만 아니라 이미 발생한 갈변화도 방지하였다고 보고 하였다. 포도 조직배양에서도 구연산이 역시 갈변화를 방 지하는 물질로 알려져 있다고 보고 되었으나, (RoubelakisAngelakis and Zivanivitc 1991), Anthony 등(2004)의 연구에서는 구연산이 갈변율도감소시키지만체세포배 발생도감소시켰다.

본 연구에서 타우린 처리가 갈변율 감소에 미치는 영향을 조사한 실험에서도 타우린 $2.5 \mathrm{mg} / 1$ 에서 $10.6 \%$ 로 $0 \mathrm{mg} / 1$ 처리 구의 갈변율 $9.2 \%$ 보다 증가하였지만 타우린 농도를 높여줄 수록 갈변율이 감소하였고 최종 $20 \mathrm{mg} / 1$ 에서 $0.8 \%$ 의 갈변율 을 보였다(Fig. 2). 그러나, $20 \mathrm{mg} / 1$ 이상의 타우린 농도에서는 갈변율의 추가적인 감소가 일어나지 않아 $20 \mathrm{mg} / 1$ 을 갈변화 감소를 위한 최적의 타우린 농도로 선정하였다. Roh 등(2013) 의 연구에서 비타민 C를 $150 \mathrm{mg} / 1$ 처리하여 $1.5 \%$ 의 낮은 갈변 율을 보였는데 본 연구에서는 $0.8 \%$ 로 제일 낮은 갈변율을 보 여 주었으며, 또한 질산은은 무처리구와 비교해서 인편이나 잎과 구근 생장에서 생장촉진효과를 보여 주지 못하였다. 구연산 처리구도 신초발생율에 있어서는 무처리구와 비슷 한 효율을 보여 주었다. 다만 구연산 $100 \mathrm{mg} / 1$ 에서 신초 수의 증가 및 생체중 증가에서 5.8 배로 우수한 효과를 보여주었 다. 본 연구에서는 $20 \mathrm{mg} / 1$ 타우린 처리도 5.5 배의 생체중 증 가를 보여 주었으나 Roh 등(2013)의 연구결과와 비교해서 통 계적으로 유의성이 높은 결과라고 판단된다.

본 연구에서 비록 타우린이 주로 동물세포나 조직에서 생 리활성촉진 기능을 나타내어 널리 사용되는 아미노산 종류 의 물질이지만 식물조직배양에서도 생체중 증가, 신초 재분 화 및 발근율 향상 그리고 갈변율 감소라고 하는 다양한 식 물생장 촉진요소에 있어서 긍정적으로 작용될 수 있음을 나 리 식물체를 재료로 실험을 수행하여 보여준 결과라고 판단 된다. 특히 과거 연구에서 나타나듯이 스트레스 환경조건 하에서 식물 캘러스나 세포가 빠른 회복력을 나타낸 사례가 있으므로 식물 스트레스 생리 연구나 캘러스 배양 또는 형질 전환 같은 스트레스가 가해지는 조건이 포함된 연구에도 매 우 유용하게 사용되리라 판단된다. 


\section{적 요}

나리는 절화용으로 대한민국에서 인기 있는 작물 중 하나로 고품질의 우수한 나리 품종이 개발되어야 한다. 이러한 우 수 품종이 개발된 후에는 고효율의 번식체계가 확립되어야 한다. 본 연구는 타우린 처리에 의해서 신초 및 구근형성, 생 체중 증가 및 발근율 향상 등의 생장촉진 효과와 갈변율 감 소효과를 통한 나리 ‘레드플레임' 품종의 기내 식물체 생육 조건 체계 확립을 위해 수행되었다.

타우린이 생장촉진물질로 효능이 있는지 검증하기 위해 타우린을 $0,2.5,5.10,15$ 및 $20 \mathrm{mg} / 1$ 을 첨가하였다. 그 결과, 타 우린 $20 \mathrm{mg} / 1$ 처리구에서 $85 \%$ 의 신초형성률을 나타내었고 생체중은 5.5 배 증가로 무처리구에서의 4.35 배보다 더 높은 증가를 보였다. 구근형성 및 발근율 촉진 효과로는 타우린 $20 \mathrm{mg} / \mathrm{l}$ 에서 $80 \%$ 의 multiple 구근 형 성률과 $82 \%$ 의 발근율을 나타내었다. 무처리구는 각각 $50 \%$ 의 multiple 구근 형성률과 $60 \%$ 의 발근율로 타우린을 첨가한 처리구의 효율이 더 높았다.

또한 타우린 $2.5 \mathrm{mg} / 1$ 처리구에서는 $10.6 \%$ 의 갈변율을 보 인 반면에, $20 \mathrm{mg} / 1$ 처리구에서 $0.8 \%$ 의 갈변율을 보여 갈변율 감소에도 효과를 나타내었다.

타우린 처리구가 생체중 증가, 신초 생성률, 발근율 및 구 근 형성 등의 전반적인 생장요인 들에 있어서 긍정적인 효과 를 보여 줌으로써 나리를 포함하는 식물조직배양에서 타우 린이 구연산 및 비타민 $\mathrm{C}$ 와 같은 항산화제 또는 아미노산 대 체제로서 사용 가능성을 보여 주었다.

\section{사 사}

이 논문은 부산대학교 기본연구지원사업 (2년)에 의하여 연 구되었음.

\section{References}

Anthony JM, Seneratna T, Dixon KW, Sivaisithamparam K (2004) The role of antioxidants for initiation of somatic embryos with Conostephium pendulum (Ericaceae). Plant Cell Tiss organ Cult 78(3):247-252

Arnaldos TL, Munoz R, Ferrer MA, Calderon AA (2001) Changes in phenol content during strawberry (Fragaria $\mathrm{X}$ ananasa, cv. Chandler) callus culture. Physiol Plant 113:315-322

Druart PH (1988) Regulation of auxiliary branching in micropropagation of woody fruit species. Acta Hort 227:369-380

Ferreira BAL, Lima-Costa ME (2006) Metabolic response to salt stress in cell suspension cultures of sensitive and resistant citrus. J Hortic Sci Biotechnol 81(6):983-987

George EF, Hall MA, De Klerk GJ (2008) Plant propagation by tissue culture. The background. $3^{\text {rd }}$ ed. Dordrecht: Springer. ISBN 978-1-4020-5004-6
Govaerts R (2013) World Checklists of Liliaceae. Royal Botanic Gardens, Kew. http//appa.kew.org/wcsp/qsearch.do.

Han DS, Niimi Y, Nakano M (1997) Regeneration of haploid plants from anther cultures of the Asiatic hybrid lily 'Connecticut King'. Plant Cell Tiss Organ Cult 47:153-158

Hao LH, He PQ, Liu CY, Chen KS, Li GY (2004) Physiological effects of taurine on the growth of wheat (Triticum aestivum L.) seedlings Zhi Wu Sheng Li Yu Fen Zi Sheng Wu Xue Bao. Chin J Plant Physiol Mol Biol 30(5):595-598

Jeong JH (1998) Effect of scale position, chilling duration and IBA on bulblet formation in scale cuttings of Lilium hansonii. Flower Res J 23:33-41

Joshi SK, Dhar U (2009) In vitro propagation from axenic explants of Lilium oxypetalum (D. Don) Baker, an endemic bulbous plant of high altitude Himalaya. Acta Physiol Plant 31: 833-838

Kim JB (2017) Optimization of a protocol for the production of transgenic lily plants via particle bombardment. J Plant Biotechnol 44:82-88

Ko WH, Su CC, Chen CL, Chao CP (2009) Control of lethal browning of tissue culture plantlets of Cavendish banana cv. Formosana with ascorbic acid. Plant Tiss Organ Cult 96(2):137-141

Lee DH (2015) In vitro analysis of taurine as anti-stress agent in tomato (Solanum Lycopersicum)-preliminary study, Taurine 9, pp75-85, Springer Switzerland

Liu J, Zhang J, Xu B, Jia C, Zhang J, Tan G, Jin Z (2011) Regeneration and production of transgenic Lilium longiflorum via Agrobacterium tumefaciens. In Vitro Cell Dev Biol-Plant 47:348-356

Marinangeli PA, Curvetto N (1997) Bulb quality and traumatic acid influence bulblet formation from scaling propagation of Lilium longiflorun. J Amer Soc Hort Sci 128:324-329

Ministry of Food, Agriculture, Forestry and Fisheries (2015) Statistics of floriculture cultivation in 2015

Murashige T, Skoog F (1962) A revised medium for rapid growth and bioassays with tobacco tissue culture. Physiol Planta $15: 473-497$

Ozygit II (2008) Phenolic changes during in vitro organogenesis of cotton (Gossypium hirsutum L.) shoot tips. Afr J Biotech 7(8): $1145-1150$

Paek KY (2001) Plant Tissue Culture, Hyang-Moon publisher, Seoul, Korea, p466

Roubelakis-Angelakis KA, Zivanivitc SB (1991) A new culture medium for in vitro rhizogenesis of grapevine (Vitis spp.) genotypes. HortSciences 26(12):1551-1553

Roh HS, Lee SI, Kang YI, Kim MS, Kim JB (2013) Effects of ascorbic acid, citric acid and silver nitrate on the growth of in vitro lily plantlets and reduction of browning. J Plant Biotechnol 40: 224-230

Tang YP, Liu XQ, Gitutu RW, Chen LQ (2010) Callus induction and regeneration from in vitro cultured leaves, petioles and scales of Lilium leucanthum (Baker) Baker. Biotechnol Biotechnol Equip 4:2071-2076

Wang Y, van Kronenburg B, Menzel T, Maliepaard C, Shen X, 
Krens F (2012) regeneration and Agrobacterium-mediated transformation of multiple lily cultivars. Plant Cell Tiss Organ Cult 111:113-122

Woo JH, Nam HH, Lee HS, Choi BK, Park IS, Kim KW (2004) Elimination of lily symptomless virus through shoot apex culture in Lilium oriental hybrids. Kor J Hor Sci Technol 22:328-332
Yoo YK, Kim BW (2006) Effect of scale position and cutting condition on bulblet formation and Growth in scaling of Lilium oriental hybrid 'Siberia' by use of perforated polyethylene film bag. J Kor Soc People Plants Environ 9(1):40-45

Zoltan M, Virag E, Ordog V (2011) Natural substances in tissue culture media of higher plants. Acta Biol Szeg 55(1):123-127 